\title{
Quantifying off-site effects of land use change: filters, flows and fallacies
}

\author{
Meine van Noordwijk ${ }^{\mathrm{a}, *}$, John G. Poulsen ${ }^{\mathrm{b}, 1}$, Polly J. Ericksen ${ }^{\mathrm{c}, 2}$ \\ ${ }^{a}$ World Agroforestry Centre (ICRAF), SE Asia Regional Program, P.O. Box 161, Bogor 16001, Indonesia \\ ${ }^{\mathrm{b}}$ Centre for International Forestry Research (CIFOR), Bogor, Indonesia \\ ${ }^{\mathrm{c}}$ ASB Global Coordination Office, ICRAF Headquarters, Nairobi, Kenya
}

\begin{abstract}
Many external effects of land use change are based on modifications of lateral flows of soil, water, air, fire or organisms. Lateral flows can be intercepted by filters and thus the severity and spatial range of external effects of land use change is under the influence of filter effects. Wherever lateral flows are involved, research results cannot be simply scaled on an area basis, and overall impact does not follow simple linear causal relationships. This complexity has consequences for relationships amongst the primary agents who initiate or exacerbate external effects, other stakeholders who are affected by them and policymakers who attempt to mitigate problems that reach sufficient visibility in society. In this paper we review how the relative importance of lateral flows and filter effects differs among a number of externalities, and the implications this has for research methods. If flows and filters are incompletely understood, policies may be based on fallacies. Whereas 'fire-breaks' act as filters in the lateral flow of the high temperature pulse of a fire, smoke from land-based fires can be intercepted only by rainfall acting as a filter and the external impact of smoke is determined by the atmospheric conditions governing lateral flow and chemical transformations along the pathway. Causal relations in smoke and haze problems are relatively simple and may form a basis for designing policy interventions to reduce downwind damage. For biodiversity issues, landscape connectivity, the absence of filters restricting dispersal and movement of organisms, is increasingly recognised as an influence on the dynamics of species richness and its scaling relations. Biodiversity research methods can extend beyond the current descriptive stage into clarifying causal relations with a lateral flow perspective. The question whether connectivity is in fact desired, however, depends on stakeholder interests and situation. Forest functions in watershed protection, presumably leading to a continuous flow of clean water in the dry season through the subsoil instead of a rapid surface transfer, have been generally attributed to the trees rather than the forest, with its rough surface structure, swamps and infiltration sites. A new synthesis of site-specific hydrological knowledge and tree water balance studies may be needed to separate myth from reality, and avoid wasting public funds on tree planting under the heading of reforestation, without restoring the hydrological regime of a real forest. Soil movement can be intercepted at a range of scales and in as far as soil transport entails movement of soil fertility, filter zones can be very productive elements of a landscape. To achieve 'integrated natural resource management' all external effects of land use will somehow have to be taken into account in farmer decision making about the use of natural resources on and off farm. Farmers' ecological knowledge may include concepts of lateral flows and should be further explored as an integral part of a new landscape ecological approach. (c) 2004 Elsevier B.V. All rights reserved.
\end{abstract}

Keywords: Biodiversity; Filters; Fire; Lateral flows; Scale effects; Watershed functions

\footnotetext{
* Corresponding author. Tel.: +62-251-315-234; fax: +62-251-315-567.

E-mail addresses: m.van-noordwijk@cgiar.org (M. van Noordwijk), ericksen@iri.columbia.edu (P.J. Ericksen).

${ }^{1}$ Present address: Wagnersvej 9, 7400 Herning, Denmark.

${ }^{2}$ Present address: International Research Institute for Climate Prediction, Columbia University, New York, USA.
} 


\section{Introduction}

The questions raised by Tomich et al. (this volume) imply a need for methods for quantifying effects of land use change across a hierarchy of scales. The economic concept of 'externalities' relates to effects outside of the analysis by the decision maker. Often, but not necessarily, these are effects at some physical distance, external to the land unit directly affected by the decision, depending on the scale and organisation of human land use (Sinclair, 1999a). Many externalities are based on (changes in) lateral interactions between land units. Lateral interactions may consist of mass flows of soil, water or air, of specific substances and organisms carried in such flows, or of active movement of organisms. Wherever 'lateral interactions' play a role, area is not an unequivocal basis for expressing results of measurements and scaling is not a trivial exercise of multiplying total area by average value per unit area. Externalities based on lateral interactions can have a complex causal relationship, as effects can be mitigated or influenced by filter functions of landscape elements at intermediate scale (Fig. 1). The location of filters is likely to be at least as important as the total area available to the land cover types that can exert this function. If flows and filters are incompletely understood, however, policies may be based on fallacies. Understanding the filters and flows, however, is a necessary but not sufficient condition for effective governance.

Trees and patches of forests can play such a filter role, giving a new dimension to research in agroforestry (Van Noordwijk and Ong, 1996). Filters can discouple flows of dissolved particles from a mass flow of water, but also act on flows of air or even organisms. Approaches of the landscape mosaic from above (remote sensing, patterns, land use planning) are complementary to those from below (lateral interactions, transport processes, farmer management decisions, stakeholder-policy-agent feedback). A landscape is here defined as a heterogeneous area made up of a cluster of interacting ecosystems/habitats, usually repeated in similar form in a regional context (Forman, 1995). Landscape structure is defined as the sizes and shapes of these patches of different habitat types (here used interchangeably with ecosystems), and the distances of these patches from one another. In agro-ecosystems the landscape organisation is closely linked to the patterns of human organisation. We will review how spatial patterns in a landscape mosaic affect the processes of lateral interactions which these externalities entail and hence the degree to which intermediate or landscape level solutions can reduce the conflicts of interest between private land use decisions and values regarded by society at large and/or specific interest groups of external stakeholders.

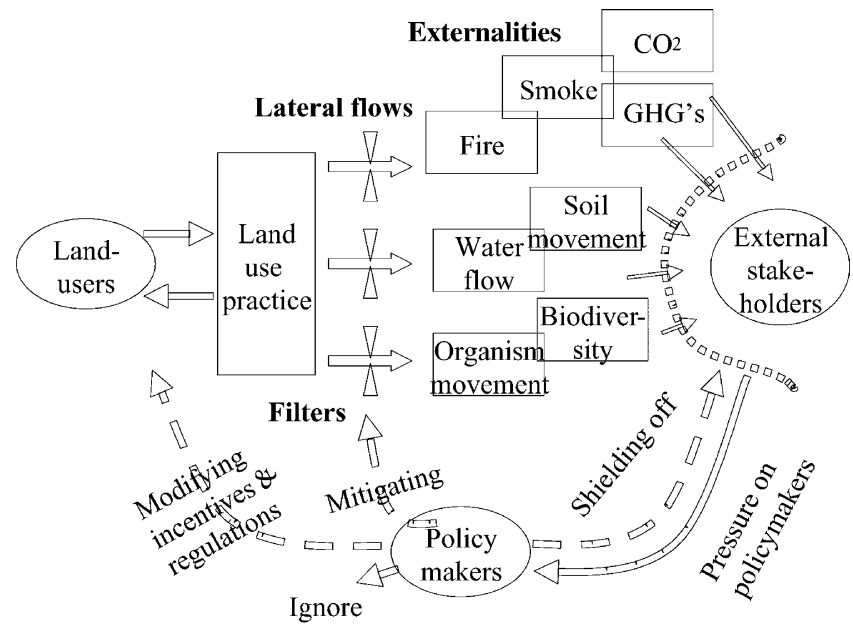

Fig. 1. Schematic relationships between land use practices, lateral flows, filter effects and external impacts, and the feedback loop from stakeholders via policymakers to efforts to modify the land use, strengthen the filter functions or shield off the external stakeholders; GHG's: greenhouse gasses. 
Table 1

'Externalities' or land use effects beyond farm level, classified by categories of lateral movement

\begin{tabular}{|c|c|c|c|c|c|}
\hline What moves? & Examples & $\begin{array}{l}\text { Approximate } \\
\text { range }(\mathrm{km})\end{array}$ & $\begin{array}{l}\text { Causing what type of }(+ \text { or }-) \\
\text { externality? }\end{array}$ & $\begin{array}{l}\text { Can flow be stopped? } \\
(++=\text { easily, }-- \\
=\text { not at all })\end{array}$ & How? \\
\hline \multirow[t]{3}{*}{ Soil/earth } & Landslides & $0.1-1$ & Physical destruction (-) & + & Forested strips as filter \\
\hline & Water-borne sediment & $10-100$ & $\begin{array}{l}\text { Siltation of reservoirs }(-) \text {, } \\
\text { fertilisation }(+)\end{array}$ & ++ & Riparian strips and vegetative filters \\
\hline & Air-borne dust & $100-1000$ & Fertilisation $(+/-)$ & + & Windbreaks \\
\hline \multirow[t]{7}{*}{ Water/solutes } & Floods & $10-100$ & Drowning and destruction $(-)$ & $+/-$ & Riparian zones and floodplains \\
\hline & Dry season river flow & $10-100$ & Off-season water supply $(+)$ & $-1+$ & Reservoirs \\
\hline & Total river water yield & $10-1000$ & Water supply (storable) $(+)$ & $-1+$ & Groundwater use \\
\hline & Groundwater recharge & $10-1000$ & Off-site water supply $(+)$ & $-1+$ & $\begin{array}{l}\text { Landscape surface roughness } \\
\text { and infiltration sites }\end{array}$ \\
\hline & Salt & $1-10$ & Salinisation (-) & $-1+$ & Salt absorbing vegetation \\
\hline & Nutrients & $1-100$ & Eutrophication $(-/+)$ & $+1-$ & Absorptive filter ('safetynet') \\
\hline & Pesticides and other chemicals & $10-1000$ & Pollution $(-)$ & $-1+$ & Absorptive (biological) filter \\
\hline \multirow[t]{6}{*}{ Air } & Wind & 0.1 & Abrasion $(-)$ & ++ & Windbreaks \\
\hline & Greenhouse gases & Global & Greenhouse gas effect $(-)$ & -- & \\
\hline & Sulphurous and nitrous oxides & 1000 & Acid rain $(-)$ & - & \\
\hline & Smoke & $1-1000$ & Smog, low visibility $(-)$ & - & \\
\hline & Air humidity & $0.01-0.1$ & Less evapotranspiration $(+)$ & + & High evaporation strips \\
\hline & Water-vapour & 10 & Effects on rainfall? $(-)$ & $-1+$ & \\
\hline Fire & High temperature pulse & $1-10$ & Destruction and burn $(-)$ & + & Fire-break \\
\hline \multirow[t]{6}{*}{ Organisms } & Free roaming predators & $0.1-10$ & Reducing pest outbreaks $(+)$ & $-1+$ & Lack of corridors connecting to refugia \\
\hline & Pollinators & $0.1-1$ & Securing fruit set $(+)$ & + & Lack of nearby patches with host plants \\
\hline & Desirable (forest) species & $0.1-1$ & $\begin{array}{l}\text { Providing spontaneously established } \\
\text { resources }(+)\end{array}$ & + & Lack of connections to nearby refugia \\
\hline & Pests and diseases & $0.1-1$ & Yield loss/crop failure $(-)$ & $+1-$ & Filters $=$ interrupted corridor \\
\hline & Weeds & $0.1-1$ & Yield loss/crop failure $(-)$ & $+1-$ & Filters $=$ interrupted corridors \\
\hline & Soil 'engineers' & $0.01-0.1$ & Repairing soil structure $(+)$ & + & Lack of nearby refugia for recolonisation \\
\hline
\end{tabular}


The main categories of problems discussed by Tomich et al. (this volume), watershed functions, smoke and biodiversity can be classified by different phases of transport: movement of earth, water, wind, fire or organisms (Table 1). Spatial relations caused by the flow of water, air and moving organisms were discussed for NW Europe by Vos and Opdam (1993).

The data required to have impact on human decisions and policies, and hence the most appropriate methods to obtain relevant data, depend on where the given 'externality' is on the 'issue life cycle' (Tomich et al., this volume).

\section{Externalities, environmental service functions and filters}

Land use change can impact on the service functions (Constanza et al., 1997) such as the supply of clean air and water, which everybody expects the environment to provide, but few want to take effort to maintain. Land use systems can be classified by their influence on on-site as well as off-site environmental service functions (Table 2).

The term 'filter' is here used in a generic sense of anything that can intervene with a lateral flow. Typically, filters occupy a relatively small fraction of the total area and have a large impact per unit area occupied. They can thus be regarded as 'keystone'

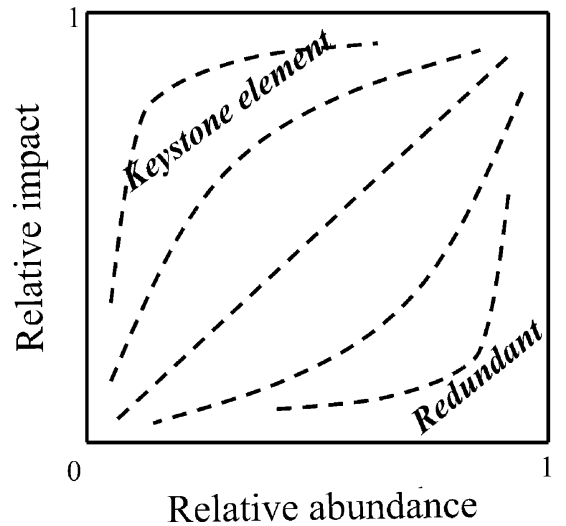

Fig. 2. Definition of 'keystone' elements of a landscape based on their large impact relative to the fraction of area occupied.

elements of a landscape (Fig. 2). Filter elements can be easily missed out in remote sensing approaches, but should be the focus of research if we want to understand how the landscape functions as a whole.

Closely coupled to the issue of filters and flows is the question of whether spatial pattern matters. A comparison of landscapes with the same relative area occupied by trees but in different spatial configurations has been at the core of 'agroforestry' research, establishing where agroforestry can be superior to the weighted mean of its 'agriculture' and its 'forestry' component (Sinclair, 1999b).

Table 2

Environmental service functions of landscape elements at a range of scales (modified from Izac and Sanchez (1999))

\begin{tabular}{|c|c|c|c|c|}
\hline & Farm & Landscape & Region & Global \\
\hline $\begin{array}{l}\text { Harvested net primary } \\
\text { production (NPP) }\end{array}$ & $\begin{array}{l}\text { Food production and income } \\
\text { generation }\end{array}$ & $\begin{array}{l}\text { Food and fuel security, } \\
\text { poverty alleviation }\end{array}$ & $\begin{array}{l}\text { Food and fuel security, } \\
\text { poverty alleviation }\end{array}$ & Reduce mass poverty \\
\hline Non-harvested NPP & Soil resource conservation & Soil and forest functions & Forest functions & Carbon storage \\
\hline $\begin{array}{l}\text { Nutrient use and } \\
\text { replenishment }\end{array}$ & $\begin{array}{l}\text { Nutrient cycling, } \\
\text { decomposition and } \\
\text { mineralisation }\end{array}$ & $\begin{array}{l}\text { Nutrient cycling, lateral } \\
\text { flows in mosaic }\end{array}$ & $\begin{array}{l}\text { Preventing depletion and } \\
\text { excess (pollution) }\end{array}$ & \\
\hline Soil movement & $\begin{array}{l}\text { Erosion control and } \\
\text { sediment retention }\end{array}$ & $\begin{array}{l}\text { Soil transfers (losses and } \\
\text { gains), characteristics of } \\
\text { streambeds and lakes }\end{array}$ & $\begin{array}{l}\text { Preventing siltation and } \\
\text { pollution }\end{array}$ & \\
\hline $\begin{array}{l}\text { Water use and } \\
\text { replenishment }\end{array}$ & $\begin{array}{l}\text { Infiltration and use of soil } \\
\text { water }\end{array}$ & $\begin{array}{l}\text { Streams and subsurface } \\
\text { water flows }\end{array}$ & River flow, aquifers & \\
\hline Climate regulation & $\begin{array}{l}\text { Microclimate for crops and } \\
\text { animals }\end{array}$ & $\begin{array}{l}\text { Effects on air turbulence and } \\
\text { rainfall distribution }\end{array}$ & $\begin{array}{l}\text { 'Teleconnections' via } \\
\text { circulation cells }\end{array}$ & $\begin{array}{l}\text { Greenhouse gas } \\
\text { concentrations }\end{array}$ \\
\hline Facilitating other biota & $\begin{array}{l}\text { Pollinators, biological } \\
\text { control agents }\end{array}$ & $\begin{array}{l}\text { Pollinators, biological } \\
\text { control agents, refugia }\end{array}$ & Refugia & Biodiversity \\
\hline
\end{tabular}




\section{Methods for scaling lateral flows}

Quantification of external impacts of land use can be approached in different ways (Table 3):

1. Approaches based on 'balance sheets' for well-defined land units (such as C-stocks, nutrient balance, water balance, and local species richness).

2. Approaches based on direct measurement of transport (mass flow of carrier plus concentrations, organism dispersal) across land units.

3. Approaches based on 'filter elements' in the landscape known to interact with lateral interactions (this may be a special form of 1).

4. Measurements of intensive parameters at a range of scales and analysis of apparent 'fractal dimensions', as indicators of lateral interactions (see below).

The use of at least two of these categories of methods may be an important consistency check (especially in early stages of the 'issue life cycle'), and may help in evaluating cost-effective monitoring schemes for routine applications.

In many disciplines past approaches were based on the notion of a 'representative elementary volume' (soil science), 'minimum sample area' (biodiversity) or 'representative farm households within agro-ecological zones' (social science and farming systems), as a unit which contained the salient properties of the system to be studied. Within such a unit, one typically assumes complete mixing, while between units substantially less exchange would occur. Overall properties are calculated by multiplying total area (or volume) with the established average value per unit area (or volume). Although valuable as a first approximation, no universal delineation of such units can be found that transcends disciplines and properties.

During the last few decades, progress was made to transcend the earlier delineation debates. Over a certain range of scales, relatively simple rules were found to apply for the scale impact. These rules may, within a certain scale range, be of the form:

$Y_{L}=Y_{1}\left(\frac{L}{L_{1}}\right)^{a}$,

where $Y_{L}$ and $Y_{1}$ are system properties at length scale $L$ and $L_{1}$, respectively; and $a$ is the dimension. If $a$ is 1 , the scaling rule is linear; for $a=2$ or 3 , the rule is area or volume based; if $a$ is not an integer, the rule is 'fractal'. The fractal dimension of species richness, for example, has been under study for over 30 years in the form of the theory of island biogeography (Rosenzweig, 1995; see below). Fractal approaches have found wide application in geography (Lam and de Cola, 1993) and landscape ecology (Farina, 1998).

Fractal properties ('dimension') apply to 'self similar' systems across scales, and can be used in extrapolating measurements of limited sample points to quantitative statements about system properties at any scale within the range where the rules apply. A fractal dimension can thus serve as a simple summary parameter for the (spatial or temporal) scaling properties of a systems attribute, and knowledge of its magnitude is often at least as important as having a precise estimate of system attributes at a particular scale of measurement (Van Noordwijk, 1999a). Crawford et al. (1999) discuss the contribution of fractal models to the integration of processes in soils, with an emphasis on soil physical properties, but also some first applications to soil biology. Recognition of the appropriate scaling rules may help to understand the risks of 'scaling up' essentially plot level nutrient

Table 3

Generic approaches to measurement of 'intensity' and 'extent' parameters of environmental functions of landscape elements

\begin{tabular}{|c|c|c|}
\hline & 'Intensity' parameter (amount per unit area or volume) & $\begin{array}{l}\text { 'Extent' parameter (total area or } \\
\text { volume influenced) }\end{array}$ \\
\hline Balance sheet & Amounts per unit land in a category & Land area in different categories \\
\hline Fluxes and flows & Concentrations of sediment, soot particles or gasses & Mass flow of water or air carrier \\
\hline Filters & $\begin{array}{l}\text { Maximum filter function per unit time per unit filter } \\
\text { element, its saturation and subsequent regeneration }\end{array}$ & Quantity and location of filter elements \\
\hline Determination of fractal dimensions & Relative contribution of lateral flow in overall process & $\begin{array}{l}\text { Empirical relations between properties } \\
\text { measured at different scales }\end{array}$ \\
\hline
\end{tabular}


Table 4

Contrast between stratified sampling approach and landscape scaling approach to estimate total value of entities over a land unit

\begin{tabular}{|c|c|}
\hline Stratified sampling & Landscape scaling \\
\hline 1. Identify internally relatively homogeneous, mutually independent strata & $\begin{array}{l}\text { 1. Identify 'landscape functional types' as mosaics of } \\
\text { interacting elements }\end{array}$ \\
\hline 2. Estimate the typical value for each stratum $\left(y_{i}\right)$ & 2. Estimate the mean value at a certain unit scale $\left(Y_{1}\right)$ \\
\hline 3. Establish the area for each stratum $\left(f_{i}\right)$ & $\begin{array}{l}\text { 3. Establish the fractal dimension }(z) \text { by repeating step } 2 \\
\text { at other scales }\end{array}$ \\
\hline 4. Multiply areas and value to get overall results: $Y_{t}=S f_{i} y_{i}$ & $\begin{array}{l}\text { 4. Scale plot results to any landscape scale } s \text { and } \\
\text { associated area } A_{s}: Y_{s}=Y_{1} A_{s}^{z} \\
\text { 5. If results are to be added for multiple landscape } \\
\text { types, estimate interaction term: } Y_{t}=S Y_{i 1} A_{i t}^{z i}\end{array}$ \\
\hline
\end{tabular}

balances to the African continent (Van Noordwijk, 1999b). The essential steps in approaches based on 'stratified sampling' and those based on 'landscape scaling' are summarised in Table 4.

The impact of measurement scale on the outcome of a measurement (even if expressed 'per unit area') may be counter-intuitive: as long as one makes sure that all elements of a population have equal chance of being represented in the measurement, one would expect sample size to influence the confidence interval, but not the mean result. Two examples may illustrate our point. First of all consider measurement of human migration, using a different measurement units, e.g. homestead, village, district, province, nation, continent, planet. Even if one makes sure to include all human beings just once in the sampling, the result expressed as fraction of migrants as part of the total population will strongly decrease with sample size, from close to $100 \%$ at home (stead) level to $0 \%$ at the planet scale. The increase of sample size has 'internalised' most of the border crossings, which define migration. What applies to human migration, applies similarly to migration of other species and explains part of the complexities in scaling biodiversity measures. Secondly, consider erosion. Plot level erosion may be high under many agricultural practices, but at a continental scale Africa loses hardly any sediment to seas and oceans, as most sediment will be trapped within terrestrial, riverine or lake habitats.

The connection between lateral flows and fractal dimensions can be further explored on the basis of this erosion/sedimentation example, by constructing maps of positive (net erosion sites) and negative (net sedimentation sites) numbers, with for example a random distribution. This map can be sampled at a range of scales (all of them covering each cell in the map just once), with the additional rule that a sample reflects the average value of the cells it contains, but cannot be negative. This latter rule is based on the conventional approach in erosion measurements where incoming sediment flows are excluded from measurement plots, and net sedimentation is thus represented by a zero result. Using such a method, the end result will be that at a measurement scale of a single unit all negative values are perceived as zero and the average result will overestimate the real value. With increasing sample size the average per unit area will decrease, until a sample size is reached at which no individual samples produce a zero result.

A plot of the logarithm of the result against the logarithm of the sample scale may produce a straight line over part of the range (fractal scaling), levelling off at some point (multiple scaling). As illustrated in Fig. 3, the slope of the line and hence the fractal dimension of the process will depend on the frequency of negative results. Scale effects over a larger part of the range are to be expected if non-random patterns of positive and negative values are introduced. A direct analogy may exist between this example and the measurement of erosion and other lateral flow surface phenomena where the filters are not counted as 'negative flows'. There is nothing mysterious about these scaling phenomena, but we are so familiar with the erroneous results of methods ignoring these issues that it takes effort to digest it.

In the remaining part of this article, we will briefly review methodological issues for the three types of externalities considered in this volume. 


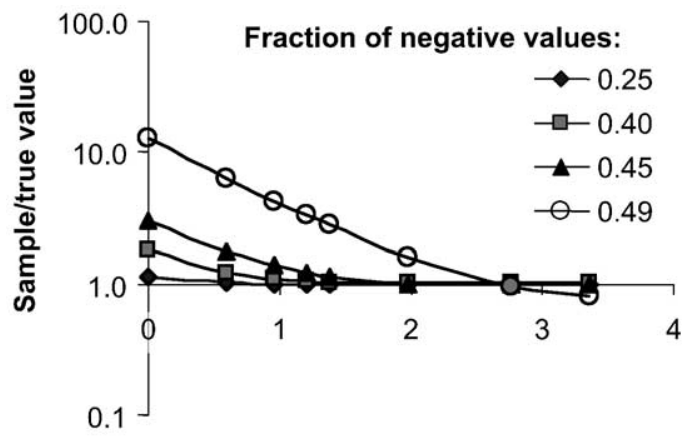

Log sample size

Fig. 3. Effect of measurement scale (log form) on average measurement result $(\log$ form $)$ for a random grid $(48 \times 48$ cells $)$ of positive and negative values, depending on the fraction of negative values (results averaged over 10 replicate randomisation's); for further explanation see text.

\section{Quantifying external effects of smoke and fire}

Transboundary haze problems as experienced in SE Asia appear to be the direct result of biomass burning (forest fires, land clearing by slash-and-burn, residue disposal, burning and smouldering of peat soils and superficial coal deposits). The debate is focussed on the reasons why people set fire to particular pieces of land ('fire as a tool, or as weapon', Tomich et al., 1998), not on the relation between fire and smoke per se. As impacts of haze are rapid and source areas can be traced by remote sensing (Murdiyarso et al., this volume), it seems that the conditions are right for a direct feedback from the stakeholders affected by the haze and smog to the land users responsible, with national policymakers involved where international relations are involved. On closer inspection, however, even this issue has lateral flow and filter aspects that may complicate policy formulation and implementation.

Malingreau and Zhuang (1999) reviewed the global significance of biomass burning. Non-methane hydrocarbons emitted by vegetation apparently play a role in the chemical transformations (including ozone formation) in the lower atmosphere, converting the primary emissions of methane, carbon monoxide and nitrous oxides to the forms, which have impact elsewhere. Rainfall is the major filter, discoupling airflow from the gasses and particulate matter it carries along. The $1997 / 1998$ smoke and haze impacts were aggravated by a lack of rainfall, an inversion situation where the normal vertical escape of air flows to higher atmospheric layers did not occur and admixture of urban and industrial emissions to the smoke and primary fire products. The relation between point source of smoke and other products of biomass burning and impacts elsewhere may not be as straightforward as it appears at first sight, but still be sufficient for policies to focus on the primary agent.

For the lateral flow of an energy pulse leading to the spread of fire, the filter function of a fire-break is a well-recognised part of landscape level design rules. Any spatially explicit model of fire occurrence needs rules for fire initiation and extinction in each landscape unit (e.g. 'pixel') and the probability of fire spread from neighbouring units. A basic form for the probability of fire occurrence in any part of a landscape could be (compare Wibowo et al., 1997):

$p(\text { fire })_{i} \quad$ (fire initiation in a land unit)

$$
\begin{aligned}
& =(I-E) F W+\sum_{j}^{8} p(\text { fire }) j\left(1-F_{\mathrm{A}}\right)\left(1-F_{\mathrm{B}}\right) \\
& \text { (spread from neighbourhood) }
\end{aligned}
$$

where $I$ is the $p$ (initiate), $E$ the $p$ (extinguish), $F$ the relative fuel factor $(0-1), W$ the relative weather factor $(0-1), F_{\mathrm{A}}$ the abiotic filter $(0-1)$ and $F_{\mathrm{B}}$ the biotic filter $(0-1)$.

The terms $I$ and $E$ primarily depend on the social actors involved and the incentives they face in initiating or extinguishing fires (in general, or under specific conditions). Research methods to quantify the biophysical model terms $\left(F, W, F_{\mathrm{A}}\right.$ and $\left.F_{\mathrm{B}}\right)$ are available and can be coupled to remote sensing characterisation of the connectivity of 'burnable' pixels. The longer-term impacts of fire on ecosystems depends strongly on the ecosystem and stakeholder perspective (Whelan, 1995).

\section{Quantifying effects of land use change on biodiversity}

As evident of the mix of + and - signs in Table 1, movements of organisms across a landscape can be deemed desirable or can pose a threat. Any change, either increasing or decreasing connectivity can change 
the biotic component of any location, leading to 'externalities'. In terms of the 'issue cycle' (Tomich et al., this volume), we see on one hand a strong drive for policy interventions (e.g. a global convention on biological diversity), yet a large degree of uncertainty and confusion still exists on causal relations and what exactly we want to protect for what reason. That discrepancy makes any implementation of where and how to apply such protection policies hard to defend where it conflicts with other interests.

No single 'correct' scale exists for describing populations or ecosystems (Bunnell and Huggard, 1999). In the lateral flow terminology, the organisms themselves move whenever the landscape provides the right type of continuity (by air, land or water for various categories of organisms). A range of measurement and modelling approaches exists for population redistribution in animals and plants (Turchin, 1998). The positive or negative interpretation of such lateral flows largely depends on the local or exotic nature of the organisms. Global biodiversity is largely due to geographic isolation and reducing such isolation can be clearly undesirable, even at a continental scale. On the other hand, fragmentation of previously continuous forests forms a clear threat for the survival of meta-populations (Harvey and Haber, 1998). Maintaining or re-establishing an 'ecological infrastructure' in derived landscapes has become a main issue in the developed, temperate parts of the world (Opdam et al., 1993). Applications in the tropics are relatively scarce. Harvey (2000) reported how 'windbreaks' can provide dispersal pathways for trees via seed-eating birds, but that small (e.g. $20 \mathrm{~m}$ ) discontinuities among forests and windbreaks can have a large impact.

Until recently (Hubbell, 2001), the most coherent theoretical framework for biological diversity (Rosenzweig, 1999) was formed by the theory of island biogeography, relating species richness $S$ at any scale $s$ to the richness at unit scale $S_{1}$ and a fractal dimension $z$ : $S_{s}=S_{1} A_{s}^{z}$. This approach first of all applies within a single type of landscape. Where multiple scaling is involved, as in the consideration of regions with multiple landscape types, a summation over the different landscape types should include a correction for the degree of overlap in species composition. The parameters in this equation have been interpreted from the balance of local extinction and recolonisation, depending on the connectivity with other suitable habitats for the species group considered (Rosenzweig, 1995). Alternative interpretations are currently debated (Harte et al., 1999; Rosenzweig, 1999; Hubbell, 2001). Species-area curves obtained in sampling within connected landscapes, however, cannot be used to predict the impacts on species richness if areas are modified, as species richness for areas which have become islands will decline over time once recolonisation rates are reduced-this means that the fractal dimension $z$ is time (or context) dependent (Kramer et al., 1997; Kunin, 1998; Rosenzweig, 1999).

Hubbell (2001) made a valiant attempt at unifying the theory of biodiversity and that on biogeography. His theory is 'neutral', in the sense that it does not rely of any differences in attributes or functions of the species that inhabit his model world-except for being identifiable by a different name or code. Yet, the theory gives an efficient (based on only a few parameters) account for many datasets on species richness of tropical forest trees, birds and insects across widely different scales. The theory builds on to the framework of the theory of island biogeography (dispersal limitations, population size effects), but 'unites' this with ideas that the current species richness of the world is a balance between the rates of 'speciation' and 'extinction'. As Hubbell states, there are essentially two views on why diversity exists:

- A 'niche assembly' theory that assumes that species can only survive competition by being 'sufficiently different' from the others and 'occupying an at least partly different niche' (i.e. intraspecific competition is supposedly stronger than interspecific competition).

- A 'random walk' or 'transient' theory that states that the numbers of all existing species tend to go up or down, and that the total diversity in any given space and time sampling frame is just a matter of chance-with, however, reasonably tight predictions about the relative frequencies of differently ranked species at different scales. The random walks of all species can, however, be constrained to maintain a constant total density of individual organisms (e.g. constant tree density per unit area), reflecting overall resource availability constraints (and hence the impacts of both intra- and interspecific competition). 
Hubbell (2001) claims that the latter framework may be sufficient to account for (nearly) all that we know quantitatively. Of course this does not disprove the 'niche assembly' concept, it only makes the concept 'redundant'. The new framework has consequences for sampling, data collection and data analysis-but can it also inform the human value problem of our efforts to slow down the current rate of biodiversity loss? The 'predictions' of Hubbell's theory on conditions for maintaining species richness are a combination of 'meta-populations', dispersal rates and connectivity, that have essentially been appreciated over the last few decades-so it does not bring many surprises from that perspective (it does add some precision to the predictions of time-patterns of losses after fragmentation). More importantly, probably, is that the theory may 'undercut' the popular functional interpretation of diversity. When current or potential future human use of specific properties of organisms are involved, the reasons for maintaining diversity of course remain valid. Where we say, however, that diversity is essential for the normal functioning of ecosystems, we may need to more carefully phrase what is meant by 'functionality'.

Noble (1999) discussed filters and concentrators in the context of landscape fragmentation and mobility of species. Animals appear, grosso modo, to be more sensitive to fragmentation and human disturbance than plants, but secondary impacts on plants may occur via animal partners required for pollination or seed dispersal, or via modified herbivore impacts on vegetation succession.

While loss of any species or genetically distinct population by definition depletes the genetic library (and hence its potential for supplying direct economic benefits to society), each extinction also has the potential for generating cascades of further losses. Although ecosystem services on a global scale are expected to depend on population diversity (Ehrlich and Daily, 1993; Daily and Ehrlich, 1994), the connection between diversity of populations and the delivery of ecosystem services at local and regional scale remains yet to be clarified. The ability of a monoculture to maintain services over a long time is subject to debate (Anderson, 1994; Vandermeer et al., 1998). Although monocultures (especially those that maintain genetic diversity in space, or maintain a rapid turnover in their genetic make-up by frequently replacing the germplasm used) may provide many ecosystem services over decades/centuries, they may be more vulnerable to catastrophic disease and/or be less resilient in the face of environmental change. Furthermore, the drastic reductions in species diversity in an ecosystem may lead to sequences of community development whose direction and consequences for ecosystem services may be very difficult to predict (Drake et al., 1993). Yet, evidence that species richness contributes directly to ecosystem maintenance and function at large is scant and inconclusive (Simberloff, 1999; Vandermeer et al., 1998). Biodiversity conservation is defensible as an end in itself; its more local role as a means to 'forest health' or agro-ecosystems resilience in an immediate neighbourhood has not yet been established (Simberloff, 1999; Kramer et al., 1997).

Considerable overlap exists between the kinds of species most sensitive to spatial structure (top predators, other large area-sensitive species, late-successional species), and those species most likely to have large influences on their ecosystems. This overlap suggests that changes in spatial structure can potentially have serious consequences at the level of ecosystem organisation.

To analyse the functional significance of biodiversity we may need to tease apart:

1. the biological and ecological organisation of a landscape and their interactions, the number of different biological units at each level of organisation;

2. the degree of similarity (overlap) in the traits or roles that biological and ecological units can play within each organisational level;

3 . the spatial configuration and its influence on individuals (foraging, dispersal) and meta-populations (local extinction and recolonisation; Harrison, 1994).

A strict 'externality' version of the biodiversity conservation question is: what is the impact of biodiversity at location $\mathrm{A}$, on the functioning of an agro-ecosystem at B. Is it important for B to maintain a forest at A, provided that the essential parts of the genetic library of $A$ remain accessible elsewhere? Many of the presumed ecological neighbourhood functions become less obvious the bigger the difference in biota between the forest and the agro-ecosystem. Many forest species, and especially the forest specialists considered most valuable from a conservation perspective, have little 
role to play in an agro-ecosystem. General predators (cats and snakes) may help to keep rats and mice populations in a rice field surrounded by forest at an acceptable level, but wild pigs, monkeys and elephants coming out of that same forest will make up for the difference. The presence of big cats (e.g. tigers) does not lead to a friendly perception of a neighbouring forest by local farmers, even if they acknowledge that tigers play a positive role in pest control.

\section{Quantifying external effects of land use via soil and water flows}

In view of the issue cycle (Tomich et al., this volume) soil and water conservation may seem to be an issue that has been largely resolved and at the end of its cycle. Many policies and regulations exist, and substantial incentive structures have been created to modify farmer's choices in land use. One may go so far as stating that considerable vested interests have been established in certain forms of soil conservation and watershed reforestation projects. Yet, the issue seems to be at the start of a new cycle, as the presumed causal relationships on which many current polices are built do not live up to scrutiny. A new wave of research efforts has started, with pioneers such as Hamilton and King (1983), Bruijnzeel (1990, 1997) and Diemont et al. (1991), and researchers attempting to tell the public at large and the policy community that their mental models may be myths (Calder, 1998).

For the public debate on water resources in SE Asia simple questions appear to remain unanswered:

- Are lowland (capital) cities frequently flooded because the uplands are deforested, or because they are situated on 'floodplains' at the mouth of the main rivers?

- Is the recharge of subsurface water flows and off-season streams by 'old-growth forests' due to the trees or to the forest with its surface roughness, swamps, and lack of channels? What does this mean for 'reforestation' instead of 'planting trees'?

- Is the water use of 'fast growing' trees (such as Eucalypts) more than proportionate to their growth rate (in the absence of $\mathrm{C} 4$ trees), and from where do they obtain their water (Calder, 1998)?

- What is the most effective location for "watershed protection' forests: top-down (covering the hilltops) or bottom-up (primarily aligning rivers and streams; Van Noordwijk et al., 1998)?

- Is the relatively high sediment delivery to marine systems in SE Asia simply due to the relatively short rivers in a geologically young landscape, or does it indicate a strong human impact?.

All SE Asian watersheds are 'exorheic' draining to oceans, as opposed to the 'endorheic' ones draining to lakes and fans, common in more continental parts of the world (compare Mungai et al., this volume). The SE Asian islands alone contribute about $20 \%$ of the world's sediments to the marine system (Hu et al., 1999). Lakes and reservoirs are the ultimate filter, discoupling the flow of sediment from the flow of water by reducing the velocity of flow to allow sedimentation. Global net sediment delivery to marine systems may have increased under human influence, but dams in many of the major rivers have led to dramatic local decreases, with all its consequences for fisheries and coastal geomorphology. Meybeck et al. (2001) concluded that more than $25 \%$ of global sediment flows already are trapped in reservoirs, but land ocean transfers of N \& P increase (while Si decreases, with impact on marine diatoms). Both increases and decreases of land-ocean transfers may have negative impacts on current marine systems. Irrigation engineers aim at reducing all river flows into the ocean to virtually zero (like the situation in the Nile and Colorado river) and using all freshwater for irrigation. At a continental scale terrestrial evapotranspiration is thus increasing, and this may reduce or reverse any effect deforestation may have on rainfall by reducing local evapotranspiration.

Forests can generate subsurface flows of water, and conventional techniques for measuring incoming and outgoing water flows at the soil surface can quantify amount, but many studies so far ignore incoming subsurface flows (Wenzel et al., 1998). Downslope lateral flow of water, either over the surface or below, is a major determinant of the coherence of landscapes. Existing models do a poor job on the subsurface part (Wood, 1999), unless specifically parameterised for a given region, as details of the pathway and variations in hydraulic conductivity matter. Human impact on these subsurface flows is little understood in general, but the position of deep-rooted trees in the landscape can often have significant influences on total water 
flow and the pathway of flows. In landscapes with subsurface salt deposits (such as SW and SE Australia, but also NE Thailand), the pathway itself is a major issue. Lateral flows at the surface, and the sediment they carry, are easily observed and get much attention. Subsurface flows are not visible and are associated with often substantial buffers, causing delays in the cause-effect chain and making it unlikely that policies to modify such flows will have an appreciable and appreciated impact at a politically significant time scale. Yet, groundwater flows can be ecological time bombs that cannot be easily controlled if issues are not resolved at the source. Layers of parent material and soil horizons of different textures have a profound influence on subsurface water flow. Soil texture and parent material influence the flow of water, as do landform shape and location (Gerrard, 1990). Landform shape, e.g. convex or concave, determines how surface water flow is channelled over both the landform in question and the surrounding landforms (Ericksen and McSweeney, 1999). Breaks in landforms, or the location of a concave footslope below a convex backslope can serve as filters, and have been exploited for agriculture, the world over. Landscape level hydrological models are needed for the details, but equally important are simple ways to 'read the landscape' for the extrapolation phase of policy action.

Forest functions in watershed protection, presumably leading to a continuous flow of clean water in the dry season, have been generally attributed to the trees in stead of the forest, with its rough surface structure, swamps and infiltration sites. A new synthesis of site-specific hydrological knowledge and tree water balance studies may be needed to separate myths from realities, and avoid wasting public funds on tree planting under the heading of reforestation.

Soil movement can be intercepted at a range of scales and in as far as soil transport entails movement of soil fertility, filter zones can be very productive elements of a landscape, at least partly offsetting loss of productivity in erosion zones (Daniels and Nelson, 1987). Little is known of the regeneration capacity of biological filters in riparian strips after temporary saturation (Lowrance, 1998).

Erosion/sedimentation research has to expand from its traditional focus on small plots (Stocking, 1998; Evans, 1993; Watson and Evans, 1991). The huge variability of soils at landscape scale, however, forms a major challenge in separating land use impact from existing background variation. Kabrick et al. (1997), restricted their samples to particular landforms, to eliminate this source of variability, and then used directional transects with logarithmically spaced intervals to sample soils, ultimately relying upon spatial variograms to estimate the correlation of soil properties with distance. Variograms are the basis for kriging, which is the tool used for the spatial extrapolation of soil properties (Burrough, 1993) to predict the characteristics of unsampled areas, along with multiple linear regressions and other more standard tools. Moore et al. (1993a) successfully predicted $70 \%$ of the distribution in soil attributes from variation in terrain attributes. Pennock et al. (1994) quantitatively assessed the impact of cultivation on soil quality over a landscape using a digital elevation model (DEM) to develop landform classification units. Moore et al. (1993b) discuss the methods available for predicting water flow and sediment redistribution. These methods have been used in a number of recent studies, e.g. Grunwald and Frede (1998). The limitation to these models are the significant data requirements, and the difficulties of using them in highly irregular environments.

Landslides are triggered (Iida, 1999) when the weight of the saturated soil column exceeds a critical value of friction on a plane of weakness, modified by degree of anchoring provided by deep tree roots. As landslides are essentially caused by subsurface flows, their frequency may depend less on land cover than commonly believed. In closed forests, however, landslides may have less downstream impact than in agriculturally used landscapes because forests may provide more effective filters around the streams. Road building has an obvious direct impact on landslide frequency, probably exceeding its indirect impacts via associated land use change (Ziegler et al., this volume). The strong connectivity provided by roads allows for high sediments delivery rates to streams of erosion products associated with roads, unless technical designs provide adequate filters.

Many studies have now documented that sediment flows in rivers are not as closely linked to ongoing erosion in uplands as previously thought. Modelling tools that include both agricultural and non-agricultural sources of sediment are now more widely in use (Baffaut et al., 1998). Careful landscape reconstructions can lead to a reconsideration 
of 'blame' attributions, and more importantly lead to more effective interventions to protect downstream interests. For example, Fryirs and Brierley (1999) described how the major land use change caused by European settlement in SE Australia led to the development of continuous channels in previously discontinuous river courses, greatly increasing sediment delivery from the catchment. Although disturbance of slopes resulted in significant movement of soil, most of this material was stored on-slope, in trapped tributary fills and along lower order drainage lines, as the slopes were effectively decoupled from the river channels. The sediment flowing out of the catchment largely originated from the riverbeds rather than from current erosion on the slopes. Tongway $(1990,1994)$ explored the role of vegetation in the degradation and restoration of rangelands, via the trapping and channelling of water and sediment. These patches range from clusters of lichens to shrubs and trees. Risser (1989) quantified the different capacities of vegetation units within a landscape to trap nutrients, patches and water, as a function of morphology, rate of water flow, sediment particle types, landscape position, size of the vegetated area, and slope.

In conclusion, the soil and water movement part of the externalities research agenda seems the most open to innovation, following up on the pioneers of a new wave in the issue cycle. The basic methods and models exist to do the job, but the research-policy debate is more complicated than for a 'new' issue. Especially where existing policies have done 'the right thing for the wrong reasons' (protecting forests for watershed functions), an over response may be expected when research results lead to a review of established wisdom and lore.

\section{Integration at farm and landscape level}

From an analytical perspective it is useful to separate the different types of flows, the way their origin is modified by land cover and land use, the way their rate of flow or coupling with substances carried along is modified by filter elements in a landscape and the impact they have on external stakeholders. But in reality certain landscape elements, in particular trees and small patches of forests, can modify a number of flows (e.g. water as well as organisms). Decisions on the management of such filters are based on the tradeoffs between positive and negative attributes of these filter elements.

Farmers in north Lampung (Indonesia), for example, readily acknowledge that maintaining a surface mulch provides a sediment filter and reduces soil erosion on slopes, but they are also convinced that it leads to more rats and snakes in their field. Removing all mulch, e.g. by burning crop residues, provides an 'animal filter' that increases their yields and makes the fields safer to work in (Gauthier, 1996).

Farmer knowledge of lateral flows and landscape relations should form a starting point for any effort to understand the rationality of their decisions on landscape elements. Local terminologies for landscape building blocks may contain more information about functional relations than recognised in remotely sensed maps. An example of farmer classification in north Thailand was described by J. Peters (pers. commun.) on the basis of his 2-year participant observation in a Karen village (Table 5). Categories such as 'forest above rice field' do not translate well into English, yet ensure lateral flows into the paddies. As such forests are normally owned by the same family as the paddy, however, and this does not entail an 'externality' in the economic sense. Riparian forests are important for providing cool water that is deemed essential for the life of the local spirit owners of the land and the water, e.g. crabs, fish, and frogs that should be found living in a healthy paddy. Other landscape relations and lateral flows in the local knowledge system again refer to the biotic relations of pests in the main food crops. Snakes and the few remaining leopard cats and civets in the still forested landscape are recognised for keeping rat populations under control. In years that the bamboo flowers and sets fruit rats and mice rapidly multiply and the following cropping season rice crops may fail, leading to famine. Lansing et al. (1998) analysed the water temple system in Bali that integrates spatial patterns of rice cultivation in relation to the lateral flows of irrigation water and of pests. Thapa et al. (1995) described a rigorous methodology that is available for further analysis of such local knowledge systems that include lateral flows.

To achieve 'integrated natural resource management' all external effects of land use will somehow have to be taken into account in farmer decision making about the use of natural resources on and off farm. 
Table 5

Landscape elements recognised by a Karen community example in the upper Mae Chaem watershed, north Thailand (J. Peters, pers. commun.)

\begin{tabular}{|c|c|c|c|c|}
\hline Landscape element & Location & Function & Accessible to & Resource use \\
\hline Watershed (ridge) forest & $\begin{array}{l}\text { On the mountain ridge separating } \\
\text { the village territory from the next } \\
\text { one }\end{array}$ & $\begin{array}{l}\text { Providing main irrigable water } \\
\text { source and clean drinking water } \\
\text { (piped to the village) }\end{array}$ & All & $\begin{array}{l}\text { Cattle grazing and collection of } \\
\text { food, and medicinal plants, hunting } \\
\text { area, NTFP collection }\end{array}$ \\
\hline Conservation forest & New category & $\begin{array}{l}\text { Conserving wild animals and } \\
\text { plants }\end{array}$ & No hunting & Cattle grazing \\
\hline Open access forest & Hills surrounding village & Providing forest products & All, with permission & $\begin{array}{l}\text { Construction wood (for house, not } \\
\text { for sale), grazing and NTFP } \\
\text { collection }\end{array}$ \\
\hline Community forest & $\begin{array}{l}\text { Hills surrounding village, but } \\
\text { closer to the village than previous } \\
\text { category }\end{array}$ & $\begin{array}{l}\text { Providing forest products, for } \\
\text { community activities }\end{array}$ & Community groups & $\begin{array}{l}\text { Wood for community structures, } \\
\text { grazing and NTFP collection }\end{array}$ \\
\hline $\begin{array}{l}\text { Bush fallow ('revolving } \\
\text { forest') }\end{array}$ & $\begin{array}{l}\text { Closer to the village than previous } \\
\text { category }\end{array}$ & Crop production, grazing land & $\begin{array}{l}\text { Privately controlled in } \\
\text { cropping years, open access } \\
\text { grazing in fallow years }\end{array}$ & $\begin{array}{l}\text { Crop yields, fodder, manure } \\
\text { transferred to homegardens, } \\
\text { grazing and NTFP collection }\end{array}$ \\
\hline Riparian forest & Along the streams and rivers & $\begin{array}{l}\text { Providing clean and cool water } \\
\text { for irrigation, maintaining the } \\
\text { spirit owners (e.g. crabs, fish } \\
\text { and frogs) in the paddy fields }\end{array}$ & All & NTFP's \\
\hline 'Forest above paddy field' & $\begin{array}{l}\text { Forest land adjacent to a } \\
\text { landowner's paddy field }\end{array}$ & $\begin{array}{l}\text { Reserved for the exclusive use } \\
\text { of the paddy owner }\end{array}$ & Private & $\begin{array}{l}\text { Commercial or subsistence gardens } \\
\text { or useful tree species }\end{array}$ \\
\hline 'Paddy field' & $\begin{array}{l}\text { Between streams and previous } \\
\text { forest category }\end{array}$ & $\begin{array}{l}\text { Rice production (+dry season } \\
\text { vegetable crop) }\end{array}$ & Private & $\begin{array}{l}\text { Rice and dry season crops; } \\
\text { cattle/buffalo grazing in dry season }\end{array}$ \\
\hline Burial forest & Close to village & Cemetery & All & - \\
\hline Birth forest & Close to village & $\begin{array}{l}\text { Burial of umbilical cords for } \\
\text { spiritual security }\end{array}$ & All & - \\
\hline Homegarden & Around house in village & Household needs & Private & $\begin{array}{l}\text { Fruit, vegetables, fodder, medicine } \\
\text { (human and animal) }\end{array}$ \\
\hline
\end{tabular}

NTFP: non-timber forest product. 
The tradeoff between externalities and private profitability can be essentially different at landscape level than at that of an 'average plot' depending on the spatial pattern of the landscape and the interactions and complementarities it entails. Further incorporation of spatially explicit landscape relations and the role of trees and forest fragments into such models may lead to a more complete evaluation of options to meet the objectives of multiple stakeholders. Yet, a major challenge of such models is to do justice to the large variation among households in the decisions they make. Agrodiversity (the genetic diversity of agriculturally used resources) at landscape scale may be largely determined by the between-farm rather than within-farm diversity, and this diversity is little appreciated in most current approaches to 'priority setting' for research, nor by dissemination and extension activities.

\section{Concluding remarks}

Recognition of lateral flows as the basis for most, if not all, externalities may lead to the identification of 'keystone elements' in a landscape that have a substantial impact by providing a filter function. Trees and small patches of forest are likely to play a major role in filter functions involving surface or subsurface flows of water and sediments, as well as in the connectivity allowing movement of organisms. Agroforestry research at landscape scale can contribute by the identification of such lateral flows and the opportunities for and limitations of filter functions. Much of the toolbox developed previously for plot level monitoring and modelling has value at the landscape scale as well, but the horizontal dimension that was carefully removed in most experimental approaches of the past (e.g. plots with deep-root trenches or exclusion of incoming run-on and sediment flows) should be reinstated. Lateral flows form an important part of the causal chain in any environmental management issue and it is time that the available methods were used.

\section{Acknowledgements}

Thanks are due to J. Peters for introducing us to local landscape knowledge in north Thailand and to many of the 1999 workshop participants for discus- sions reflected in this paper. Chin Ong, Fergus Sinclair, Mike Swift and Tom Tomich provided thoughtful comments on an earlier version of this manuscript.

\section{References}

Anderson, J.M., 1994. Functional attributes of biodiversity in land use systems. In: Greenland, D.J., Szabolcs, I. (Eds.), Soil Resilience and Sustainable Land Management. CAB International, Wallingford, UK, pp. 267-290.

Baffaut, C., Nearing, M.A., Govers, G., 1998. Statistical distributions of soil loss from runoff plots and WEPP model simulations. Soil Sci. Soc. Am. J. 62, 756-763.

Bruijnzeel, L.A., 1990. Hydrology of Moist Tropical Forests and Effects of Conversion: A State of Knowledge Review. UNESCO International Hydrological Programme, Paris, 224 pp.

Bruijnzeel, L.A., 1997. Hydrology of forest plantations in the tropics. In: Nambiarand, E.K.S., Brown, A.G. (Eds.), Management of Soil, Nutrients and Water in Tropical Forest Plantations. ACIAR, Canberra, Australia, pp. 125-167.

Bunnell, F.L., Huggard, D.J., 1999. Biodiversity across spatial and temporal scales: problems and opportunities. For. Ecol. Manage. $115,113-126$.

Burrough, P.A., 1993. Soil variability: a late 20th century view. Soils Fert. 56, 529-562.

Calder, I., 1998. Water resources and land use issues. System-wide Initiative on Water Management, SWIM Paper 3. International Water Management Institute, Colombo, Sri Lanka.

Constanza, R., d'Arge, R., de Groot, R., Farber, S., Grasso, M., Hannon, B., Limburg, K., Naeem, S., O’Neill, R.V., Paruelo, J., Raskin, R.G., Sutton, P., van den Belt, M., 1997. The value of the world's ecosystem services and natural capital. Nature 387, 253-260.

Crawford, J.W., Pachepsky, Y.A., Rawls, W.J. (Eds.), 1999. Integrating Processes in Soils Using Fractal Models. Geoderma 88, 3-4 (special issue).

Daily, G.C., Ehrlich, P.R., 1994. Population extinction and the biodiversity crisis. In: Mãler, K.G., Folke, C., Holling, C.S., Jansson, B.O. (Eds.), Biodiversity Conservation: Problems and Policies. Kluwer Academic Publishers, Dordrecht.

Daniels, R.B., Nelson, L.A., 1987. Soil variability and productivity: future developments. In: Boersma, L.L. (Ed.), Future Developments in Soil Science Research. Soil Science Society of America, Madison, WI, USA, pp. 279-293.

Diemont, W.H., Smiet, A.C., Nurdin, 1991. Re-thinking erosion on Java. Neth. J. Agric. Sci. 39, 213-224.

Drake, J.A., Flum, T.E., Witteman, G.J., Voskuil, T., Hoylman, A.M., Creson, C., Kenny, D.A., Huxel, G.R., Larue, C.S., Duncan, J.R., 1993. The construction and assembly of an ecological landscape. J. Anim. Ecol. 62, 117-130.

Ehrlich, P.R., Daily, G.C., 1993. Population extinction and saving biodiversity. Ambio 22, 64-68.

Ericksen, P.J., McSweeney, K., 1999. Fine-scale analysis of soil quality for various land uses and land forms in central Honduras. Am. J. Alternative Agric. 14, 146-157. 
Evans, R., 1993. On assessing accelerated erosion of arable land by water. Soils Fert. 56, 1285-1293.

Farina, A., 1998. Principles and Methods in Landscape Ecology. Chapman \& Hall, London.

Forman, R.T.T., 1995. Land Mosaics, the Ecology of Landscapes and Regions. Cambridge University Press, Cambridge.

Fryirs, K., Brierley, G.J., 1999. Slope-channel decoupling in Wolumla catchment, New South Wales, Australia: the changing nature of sediment sources following European settlement. Catena 35, 41-63.

Gauthier, R., 1996. Vertebrate pests, crops and soil: the case for an agroforestry approach to agriculture on recently deforested land in North Lampung. AGRIVITA 19, 206-212.

Gerrard, A.J., 1990. Soil variations on hillslopes in humid temperate climates. Geomorphology 3, 225-244.

Grunwald, S., Frede, H.G., 1998. Application of AGNPSm in German watersheds. Wiener Mitteilg. Wasser-AbwasserGewaesser-experiences with soil erosion models. Bd. 151, 183189.

Hamilton, L.S., King, P.N., 1983. Tropical Forested Watersheds: Hydrologic and Soils Response to Major Uses or Conversions. Westview Press, Boulder, CO, USA, 168 pp.

Harrison, S., 1994. Metapopulations and conservation. In: Edwards, P.J., Webb, N.R., May, R.M. (Eds.), Large-scale Ecology and Conservation Biology. Blackwell, Oxford.

Harte, J., Kinzig, A., Green, J., 1999. Self-similarity in the distribution and abundance of species. Science 284, 334-336.

Harvey, C.A., 2000. Windbreaks enhance seed dispersal into agricultural landscapes in Monteverde, Costa Rica. Ecol. Appl. $10,155-173$.

Harvey, C.A., Haber, W.A., 1998. Remnant trees and the conservation of biodiversity in Costa Rican pastures. Agrofor. Syst. 44, 37-68.

Hu, D., Saito, Y., Kempe, S., 1999. Sediment and nutrient transport to the coastal zone. In: Galloway, J.N., Melillo, J.M. (Eds.), Asian Change in the Context of Global Climate Change. Cambridge University Press, Cambridge, UK, pp. 245-270.

Hubbell, S.P., 2001. The Unified Neutral Theory of Biodiversity and Biogeography. Monographs in Population Biology 32. Princeton University Press, Princeton.

Iida, T., 1999. A stochastic hydro-geomorphological model for shallow landsliding due to rainstorm. Catena 34, 293-313.

Izac, A.M., Sanchez, P.A., 1999. Towards a natural resource management paradigm for international agriculture: example of agroforestry research. Agric. Syst. 69, 5-25.

Kabrick, J.M., Clayton, M.K., McBratney, A.B., McSweeney, K., 1997. Cradle-knoll patterns and characteristics on drumlins in Northeastern Wisconsin. Soil Sci. Soc. Am. J. 61, 595-603.

Kramer, R., Van Schaik, C., Johnson, J. (Eds.), 1997. Last Stand: Protected Areas and the Defense of Tropical Biodiversity. Oxford University Press, New York, 242 pp.

Kunin, W.E., 1998. Extrapolating species abundance across spatial scales. Science 281, 1513-1515.

Lam, N.S.N., de Cola, L., 1993. Fractals in Geography. PTR Prentice-Hall, Englewood Cliffs, NJ, USA, 308 pp.

Lansing, J.S., Kremer, J.N., Smuts, B.B., 1998. System-dependent selection, ecological feedback and the emergence of functional structure in ecosystems. J. Theor. Biol. 192, 377-391.
Lowrance, R., 1998. Riparian ecosystems as filters for nonpointsource pollution. In: Pace, M.L., Groffman, P.M. (Eds.), Successes, Limitations and Frontiers in Ecosystem Science. Springer, Berlin, pp. 113-141.

Malingreau, J.P., Zhuang, Y.H., 1999. Biomass burning: an ecosystem process of global significance. In: Galloway, J.N., Melillo, J.M. (Eds.), Asian Change in the Context of Global Climate Change. Cambridge University Press, Cambridge, UK, pp. 101-127.

Meybeck, M.P., Green, P., Vororsmarty, C.J., 2001. A new typology for mountains and other relief classes: an application to global continental water resources and population distribution. Mountain Res. Dev. 21, 34-45.

Moore, I.D., Gessler, P.E., Nielsen, G.A., Peterson, G.A., 1993a. Soil attribute prediction using terrain analysis. Soil Sci. Soc. Am. J. 57, 443-452.

Moore, I., Turner, A.K., Wilson, J.P., Jenson, S.K., Band, L.E., 1993b. GIS and land-surface-subsurface process modeling. In: Goodchild, M.F., et al. (Eds.), Environmental Modeling and GIS. Oxford University Press, Oxford, UK, pp. 197-230.

Noble, I.R., 1999. Effect of landscape fragmentation, disturbance and succession on ecosystem function. In: Tenhunen, J.D., Kabat, P. (Eds.), Integrating Hydrology, Ecosystem Dynamics and Biogeochemistry in Complex Landscapes. Wiley, Chichester, UK, pp. 297-312.

Opdam, P., Van Apeldoorn, R., Schotman, A., Kalkhoven, J., 1993. Population responses to landscape fragmentation. In: Vos, C.C., Opdam, P. (Eds.), Landscape Ecology of a Stressed Environment. IALE Studies in Landscape Ecology No. 1. Chapman \& Hall, London, pp. 147-171.

Pennock, D.J., Anderson, D.W., de Jong, E., 1994. Landscape-scale changes in indicators of soil quality due to cultivation in Saskatchewan, Canada. Geoderma 64, 1-19.

Risser, P.G., 1989. The movement of nutrients across heterogenous landscapes. In: Clarholm, M., Bergstrom, L. (Eds.), Ecology of Arable Land. Kluwer Academic Publishers, Dordrecht, pp. 247-251.

Rosenzweig, M.L., 1995. Species Diversity in Space and Time. Cambridge University Press, Cambridge, UK, 436 pp.

Rosenzweig, M.L., 1999. Heeding the warning in biodiversity's basic law. Science 284, 276-277.

Simberloff, D., 1999. The role of science in the preservation of forest biodiversity. For. Ecol. Manage. 115, 101-111.

Sinclair, F.L., 1999a. A general classification of agroforestry practice. Agrofor. Syst. 46, 161-180.

Sinclair, F.L., 1999b. The agroforestry concept-managing complexity. Scot. For. 53, 12-17.

Stocking, M., 1998. Measuring and assessing the impacts of erosion: the particular challenges on communal rangelands in Africa. Paper presented at the SACRAN Communal Rangelands Symposium, Fort Hare, 6-9 July, 1998. Available from: www.uea.ac.uk/dev/publink/stocking/ms98c.shtml.

Thapa, B., Sinclair, F.L., Walker, D.H., 1995. Incorporation of indigenous knowledge and perspectives in agroforestry development. Part Two. Case-study on the impact of explicit representation of farmers' knowledge. Agrofor. Syst. 30, 249261. 
Tomich, T.P., Fagi, A.M., de Foresta, H., Michon, G., Murdiyarso, D., Stolle, F., van Noordwijk, M., 1998. Indonesia's fires: smoke as a problem, smoke as a symptom. Agrofor. Today 10, 4-7.

Tongway, D.J., 1990. Soil and landscape processes in the restoration of rangelands. Aust. Rangeland J. 12, 54-57.

Tongway, D.J., 1994. Rangeland Soil Condition Assessment Manual. CSIRO Publications, Australia.

Turchin, P., 1998. Quantitative Analysis of Movement: Measuring and Modeling Population Redistribution in Animals and Plants. Sinauer Associates, Sunderland, MA, USA, 396 pp.

Vandermeer, J., Van Noordwijk, M., Ong, C., Anderson, J., Perfecto, Y., 1998. Global change and multi-species agroecosystems: concepts and issues. Agric. Ecosyst. Environ. $67,1-22$.

Van Noordwijk, M., 1999a. Nutrient cycling in ecosystems versus nutrient budgets of agricultural systems. In: Smaling, E., Oenema, O., Fresco, L. (Eds.), Nutrient Cycles and Nutrient Budgets in Global Agro-ecosystems. CAB International, Wallingford, pp. 1-26.

Van Noordwijk, M., 1999b. Scale effects in crop fallow rotations. Agrofor. Syst. 47, 239-251.

Van Noordwijk, M., Ong, C.K., 1996. Lateral resource flow and capture-the key to scaling up agroforestry results. Agrofor. Forum 7, 29-31.

Van Noordwijk, M., Van Roode, M., McCallie, E.L., Lusiana, B., 1998. Erosion and sedimentation as multiscale, fractal processes: implications for models, experiments and the real world. In: Penning de Vries, F., Agus, F., Kerr, J. (Eds.), Soil Erosion at Multiple Scales, Principles and Methods for Assessing Causes and Impacts. CAB International, Wallingford, pp. 223-253.

Vos, C.C., Opdam, P. (Eds.), 1993. Landscape Ecology of a Stressed Environment. Chapman \& Hall, London, 310 pp.

Watson, A., Evans, R., 1991. A comparison of estimates of soil erosion made in the field and from photographs. Soil Till. Res. $19,17-27$.

Wenzel, W.W., Unterfrauner, H., Schulte, A., Ruhiyat, D., Simonrangkir, D., Kuraz, V., Bradstetter, A., Blum, W.E.H., 1998. Hydrology of acrisols beneath Dipterocarp forests and plantations in East Kalimantan, Indonesia. In: Schulte, A., Ruhiyat, D. (Eds.), Soils of Tropical Forest Ecosystems. Springer, Berlin, pp. 62-72.

Whelan, R.J., 1995. The Ecology of Fire. Cambridge University Press, Cambridge, UK, 346 pp.

Wibowo, A., Suharti, M., Sagala, A.P.S., Hibani, H., Van Noordwijk, M., 1997. Dealing with fire on Imperata grasslands as part of agroforestry development in Indonesia. Agrofor. Syst. 36, 203-217.

Wood, E.F., 1999. The role of lateral flow: over- or underrated. In: Tenhunen, J.D., Kabat, P. (Eds.), Integrating Hydrology, Ecosystem Dynamics and Biogeochemistry in Complex Landscapes. Wiley, Chichester, UK, pp. 197-215. 